\title{
ФУНКЦІОНУВАННЯ ГЕНДЕРНИХ СТЕРЕОТИПІВ У РОМАНІ О. ІЛЬЧЕНКА «КОЗАЦЬКОМУ РОДУ НЕМА ПЕРЕВОДУ..."
}

У статті розглянуто функціонування гендерних стереотипів у романі О. Ільченка "Козацькому роду нема переводу...» як творі художньої літератури, у якому висвітлено етнолінгвістичні норми гендерної культури українського народу. Проаналізовано гендерні стереотипи на позначення віку, зовнішності, соціальних ролей і психологічних особливостей, що вможливило зробити висновок про схожість гендерних стереотипів минулого й сучасності. Виокремлено стереотипізовані риси зовнішності та вікові характеристики чоловіків і жінок. З'ясовано, що соціальні стереотипи виражені передусім сімейними ролями. Виокремлені психологічні стереотипи вказують на позитивну оцінку чоловіка й часто негативну жінки.

Ключові слова: вікові стереотипи, гендерна культура, гендерний стереотип, етнолінгвістичні норми, психологічний стереотип, соціальний стереотип, стереотипи зовнішності.

Lobachova I., Pomyrcha S. Functioning of Gender Stereotypes in O. Ilchenko's Novel "Cossack Family Has No End...» The study of Ilchenko's oeuvre is relevant in the context of gender studies, because it allows both to reflect the life picture of the Ukrainian people in the early $17^{\text {th }}$ century, and to explore the functioning of gender stereotypes at that time and compare their range with those in modern Ukrainian society.

The topicality of the research is determined by the need to study the linguistic material - O. Ilchenko's novel "Cossack Family Has No End, or Mamai and a Stranger Girl" - in a new aspect, through gender linguistics, including how time and changes in society affect gender stereotypes.

The purpose of the research is to analyze the peculiarities of functioning of gender stereotypes in the language of the mentioned novel. Such methods as analysis and synthesis (to generalize scientific theories and concepts), descriptive and comparative methods (for classifying gender stereotypes) are used in the research to achieve this purpose.

It has been found out that gender stereotypes in the language confirm the peculiarities of the mentality of certain people, and with their help it is possible to study the existing ethnolinguistic norms of written gender culture. Gender stereotypes to denote age, appearance, social roles and psychological characteristics had been analyzed, which allowed to conclude the similarity of gender stereotypes of the past and present. 
Thus, a woman attaches more importance to her appearance, always strives to be attractive and young, and for men age is not so important, because over the years they become smarter. The studied stereotypes of appearance prove the presence of such stereotyped traits for men: tall, strong, with beautiful hair; for women: beautiful, slender (or prone to fullness), with beautiful hair, well-groomed body and pleasant facial features.

It has been found out that social stereotypes are expressed by family roles (attention to the role of mother and wife, while husbands are more committed to politics). A faithful, kind, beautiful woman who is also a good housewife and a strong, courageous man who can lead and support the family are positively evaluated.

The analyzed psychological stereotypes indicate a positive assessment of a man (strong, strong-willed, smart, reliable, more determined, purposeful and persistent) and often a negative assessment of a woman (more talkative, unreliable, emotional, more conflicted and not as smart as men).

Key words: gender, gender linguistics, gender role, gender stereotype, gender equality (inequality), linguistic picture of the world.

\section{Вступ}

Свідомість людини має здатність відображати навколишню об'єктивну реальність, формуючи суб'єктивний образ об'єктивного світу, утворюючи певну модель - картину світу. У процесі об'єктивізації дійсності свідомість створює так звані механізми стереотипізаціï, результатом чого є формування стереотипів (Сбітнєва, 2009: 284), які внаслідок реалізації в мовній системі стають мовними стереотипами. У мовній картині світу гендер відтворюється у вигляді гендерного стереотипу, що виявляється на всіх мовних рівнях.

Від часу появи гендерних студій у вітчизняній науковій мовознавчій практиці (XX ст.) дослідження гендерних ролей, що їх виконують індивіди, стало майже невід'ємним атрибутом поля вивчення сучасних мовознавців (Т. Василевська, Т. Говорун, П. Горностай, В. Городяненко, О. Горошко, Т. Дороніна, Н. Ісакова, І. Калько, О. Кізь, О. Кікінежді, О. Костюк, Р. Ліончук, І. Лобачова, Т. Марценюк, С. Помирча, М. Пірен та ін.).

Вивчення творчості Олександра Ільченка $є$ актуальним у контексті гендерології, оскільки дає змогу не лише відобразити картину життя українського народу на початку XVII ст., а й дослідити функціонування гендерних стереотипів у той час, а також зіставити ïx спектр із тими, що наявні в сучасному українському суспільстві. 
Актуальність теми дослідження визначено необхідністю проаналізувати лінгвістичний матеріал - роман О. Ільченка «Козацькому роду нема переводу, або ж Мамай і Чужа Молодиця» - в аспекті гендерної лінгвістики, зокрема вплив часу й особливостей суспільства на гендерні стереотипи.

Мета роботи - дослідити особливості функціонування (підтвердження чи спростування) гендерних стереотипів у мові роману О. Ільченка «Козацькому роду нема переводу, або ж Мамай і Чужа Молодиця». Основними завданнями статті визначено: 1) з'ясувати функціональне навантаження терміна «гендерний стереотип» у науковому колі; 2) проаналізувати наявні в тексті роману стереотипи на позначення віку, зовнішності, соціальних ролей і психологічних особливостей.

\section{Методи дослідження}

Для досягнення поставленої мети в роботі застосовано такі методи: аналіз і синтез - для узагальнення наукових теорій та концепцій; описовий і порівняльно-зіставний методи - для класифікації гендерних стереотипів.

\section{Виклад основного матеріалу}

Гендер як система знань - це комплекс соціально-філософських, соціологічних, політологічних, психологічних, культурологічних та інших теорій, що аналізують розвиток чоловічої і жіночої ідентичностей та суб'єктивності, становище жінки й чоловіка в суспільстві, систему чоловічого домінування, а також формування нормативних зразків «чоловічого» та «жіночого» в певній культурі. За останні роки помітно зріс інтерес до проблеми гендерної рівності (нерівності). Її можна розглядати в аспекті особливостей сприйняття індивідами різних статей відмінностей між чоловіками й жінками, а також їх оцінки.

У свідомості людини з моменту народження і до глибокої старості формується значна кількість стереотипів. У наукових дослідженнях виокремлюють позитивні, негативні й нейтральні стереотипи. За сферою формування і функціонування їх поділяють на чотири типи: особисті, сімейні, суспільні та гендерні. Останні $є$ культурно й соціально зумовленими думками про якість, атрибути й норми поведінки осіб обох статей і відображаються в мові. 
Унаслідок засвоєння гендерних стереотипів, гендерних ролей, гендерних установок та інших елементів гендерної культури суспільства відбувається процес статеворольової соціалізації індивідів, що детермінує ставлення людей до тих чи тих соціальних груп. Соціальна проблема гендерної рівності (нерівності) криється в дисгармонійності процесу статеворольової соціалізації, у відхиленнях гендерної ідентичності, зрілості, якої людина набуває в підлітковому віці. Соціологи стверджують, що гендерні стереотипи значно впливають на гендерну соціалізацію (Городяненко, 2003). Загалом аналіз впливу гендеру зводиться переважно до вивчення соціальних моделей поведінки, очікуваної від індивідів, відповідно до уявлень суспільства про «чоловіче» й «жіноче».

За словами П. Горностая, гендерна роль - це статева роль, що має суспільне забарвлення, несе в собі людський досвід, накопичений у поведінці багатьох поколінь чоловіків і жінок (Горностай, 2010). Гендерні ролі не виникають одразу з народженням дитини, вони розвиваються залежно від багатьох умов і чинників упродовж людського життя. Від цього залежить характер життєвого сценарію людини в різноманітних ситуаціях. Є почуття, що їх переживають лише жінки або лише чоловіки; є смисли, які формуються у свідомості лише жінки чи лише чоловіка, а отже, є відповідний цим настановам вибір мовних засобів, природний для одних і неактуальний, необов'язковий для інших (Горошко, 2001: 354).

Гендерні стереотипи проявляються в усіх текстуальних мовних виявах. Особлива увага до них пов'язана з тим, що вони здатні закріпити в мові саме ті еталони, під час уживання яких проявляється властивий для тієї чи тієї соціальної спільноти менталітет. Крім того, за допомогою стереотипів можна дослідити культурні й духовні установки щодо того, яким має бути об’єкт відносин в аспекті чинних норм, або норм, що існували в минулому. Отже, гендерно маркований мовний контекст є не лише засобом вираження, а й джерелом формування гендерних стереотипів.

У цьому аспекті важливим $є$ звернення до літератури, у якій висвітлюють гендерні стереотипи минулого, що допомагає з'ясувати й оцінити трактування гендерних проблем у соціумі того часу. До ключових гендерних стереотипів належать стереотипи зовнішності, віку, соціальні та психологічні. 
Традиційно в мовній картині світу зовнішності чоловіка й жінки надавали вагомого значення, хоча й різного щодо до кожної статі. Стереотипи зовнішності - один з найважливіших фрагментів відображення мовної картини світу. У кожній культурі наявні еталони чоловічої і жіночої зовнішності, що становлять сукупність ознак, пов’язаних з певними фізичними особливостями обох статей і співвіднесених з ними естетичних особливостей. Первинна оцінка за зовнішністю $є$ типовою для української культури. У сучасному суспільстві побутує думка, що цінність жінки полягає в ії красі, а красиве тіло забезпечує іï привабливість. Знаходимо підтвердження цьому й у романі О. Ільченка, наприклад: ...nан Демид любовно споглядав не тільки повіко своєї жіночки, щедро облямоване шовковим брамом вій, чорних, пухнастих, важких і задовгих, аж наче неймовірних, мов у казиі, не тільки принадно закопилену губку, рясно прикроплену потом ... а й надовго втуплював свій чоловічий погляд у пружні ї̈ перса, які, округлі, немов чаші, прагнули в різні боки (Ільченко, 2009: 7); Я люблю його, білобумажне твоє тіло, - пристрасно заговорив Пампушка, - сахарні твої уста, павину ходу твою, чорного соболя брови, сірого яструба зір, звабливу мову, твої руки чіпкі, твої зуби тхорині... (Ільченко, 2009: 16).

Чоловіки захоплюються жіночими рисами, що асоціюються з юністю, здоров'ям і, відповідно, гарним репродуктивним потенціалом (зовнішні ознаки наявності достатньої кількості жіночих статевих гормонів: пружні груди, плаский живіт). У досліджуваному романі це відображається в таких мікротекстах: ...всього в неї - $\boldsymbol{i}$ в $\boldsymbol{n a -}$ зусі, i скрізь - набралося вже досить (Ільченко, 2009: 9); Не хочеш ластівочку сою попоносити? Ось бачиш, яка я, візьми! - I пані вихвалялася в Михайлика на руках, і щось там, тепло хитнувшись, визирало 3-під розхристаної запаски, і хлопець, коли б він був поетом, обов'язково подумав би в ту мить про стиглу суничку, - не про полуницю, а про дрібну лісову суничку, бо ж пані Роксолана ще не мала й не годувала дітей, - але Михайлик не був поетом, івін подумав лише про хиткий білоцвітний кетяг калини з несподівано дозрілою червоною ягідкою на вершині опуклості ... (Ільченко, 2009: 13); - А ти? А ти? присікався обозниц̆, приступивщи до дружини й тедве досягаючи ї пишних грудей (Ільченко, 2009: 23). 
Жінки ж цінували такі чоловічі риси, що вказували на здатність бути годувальником і захисником. Зокрема, чоловіки здаються привабливими, коли їхні обличчя (невеликі очі, широкий лоб, випуклі надбрівні дуги, густі брови, випуклі вилиці, тонкі губи, великі щелепи, підборіддя видається вперед) і поведінка свідчать про зрілість та владність (Помирча, 2009). Звертають увагу й на ознаки здоров’я: зріст вище середнього, розвинена мускулатура, співрозмірність зап'ястків і щиколоток; це знаходить підтвердження в таких контекстах: Здоровенний, важкий, він ступав напрочуд легко, як величезний кіт-воркіт (Ільченко, 2009: 9); Роксолана знизу дивилася на обличия Михайликове, від сония червоне, як халява, на винозорі соколині очі, на вперту складку біля нижньої губи... (Ільченко, 2009: 14); ... ией велетень... (Ільченко, 2009: 14); Та Михайлик, парубійко прездоровий і лагідний, як лось, нівроку йому, такий вибухався, що був на голову вищий од усіх (Ільченко, 2009: 9); Тільки очі. А вони в зухвалого козака вродилися й справді прегарні, аж моторошно ставало від його погляду (Ільченко, 2009: 39); Це були очі, щзо в їхню глибінь, випадково людину зустрівщи на вулиці, як у таємничу криницю, зазирають жінки (Ільченко, 2009: 40).

Крім узагальнених стереотипів, кожна людина має власний ідеал краси. Але такі індивідуальні еталони часто нечіткі й різноманітні. Отже, привабливість не можна вважати лише індивідуальним враженням, вона має соціальний характер. Головним фактором $€$ не стільки специфічна форма носа чи колір очей, довжина й колір волосся тощо, а соціальне значення тієї чи тієї ознаки зовнішності. Оскільки є схвалювальні й несхвалювальні типи зовнішності, то привабливість це ступінь наближення до того типу зовнішності, що максимально прийнятий і схвалений групою, до якої ми належимо. Тобто зусилля людини бути схожою на соціально схвалений стандарт, відповідати суспільним естетичним стереотипам, що існують у їі субкультурі, діагностуються як знак їі прагнення бути привабливою.

Недоліками чоловічої зовнішності вважають маленький зріст, зайву вагу й надмірну худобу, наприклад: Пика ти упирева! Щуиі зуби, вовчий рот, ведмежа голова, сичеві очі (Ільченко, 2009: 17); Аж надто опасистий та огрядний, пан Демид, важкий та куиий, ледачий та запанілий... (Ільченко, 2009: 21); ...ніяковів хлопецьь, бо ж він завие соромився зросту свого й неоковирності (Ільченко, 2009: 25); ...моторний товстун (Ільченко, 2009: 7). 
Оскільки зовнішність за стереотипами менш важлива для чоловіків, тому чоловіка, який приділяє багато уваги своїй зовнішності, сприймають іронічно, що, зокрема, описано й у досліджуваному романі, наприклад: В'янучи в погляді дівочого глуму, бідолашний шляхтич намагався трішки причепуритись після перебування в мішку. Пригладжував чуб. Обсмикував на рукавах закавраші. Поправляв китички на зелених чоботях. Хоч $і$ без того все лишилось на ньому охайне і непожмакане, $і$ він увесь був приємний та гарненький, і такою лагідною посмішкою осяяло раптом його зніяковіле обличчя, щь дівчатка враз принишкли,начебто вчинили щьось недобре супроти такого хорошого чоловіка (Ільченко, 2009: 332).

Проаналізувавши мовні одиниці на позначення стереотипів зовнішності, робимо висновок, що значна їх кількість побудована на опозиції гарний - негарници, привабливий - непривабливий. Отож згідно зі стереотипами красивим вважається високий, сильний, міцний чоловік з гарним волоссям. Що ж до жінки, то красивими вважаються стрункі жінки з довгими ногами, гарним волоссям, доглянутим тілом і приємними рисами обличчя.

Вікові стереотипи в досліджуваному романі представлені меншою кількістю мовних одиниць, ніж стереотипи зовнішності. Серед досліджуваних стереотипів більша частина характеризує вік жінок, а не чоловіків, оскільки вважають, що чоловіки не надають великого значення віку, хоча у творі знаходимо й численні вказівки на вікові особливості персонажів, наприклад: ...як зиркали ви нині на якогось молоденького голодрания (Ільченко, 2009: 308); Пані Роксолану легко переносив на руках через воду один із його наймитів, молоденький коваль Михайлик (Ільченко, 2009: 8); - Чумаки, - голосом пані Роксолани, напродиво схоже на неї, відповів молодий, і пан Купа - Стародупський обернувся до жінки (Ільченко, 2009: 23); Його дратувало вже, щзо той чудернацький молодик-запорожець стиха чогось регоче над якоюсь товстою чужинного друку, досить - таки пошарпаною книгою (Ільченко, 2009: 74).

Можливо, це зумовлено тим, що для чоловіка важливішим $є$ його здоров'я, фізичний стан, аніж краса й зовнішність: ... і такий дужий, же сам - один добре вигодувану свиню міг підняти й однести світ заочі чи навіть корову, а не те що таке чудове створіння, як мила пані Роксолана Купа (Ільченко, 2009: 9). 
Для жінок існують певні, знову ж таки стереотипні, встановлені вікові рамки, зокрема більшу увагу чоловіки приділяють молодим жінкам, наприклад: ...молоденькій дружиноньиі (Ільченко, 2009: 304); ...молодесенька господиня (Ільченко, 2009: 292); ...молодичка (Ільченко, 2009: 201); До покою з лоскотливим сміхом не вбігла, не впливла, а шугонула райською птицею вісімнадиятилітня пані Роксолана Купа (Ільченко, 2009: 150); Але молоденька пані сіла (Ільченко, 2009: 8); - Як же так? Сполошилась, підійшовши до ридвана, матінка Михайликова, невеличка, змучена злиднями та горем, але ще кругленька, мов ичибулька, й зовсім іще не стара матуся (Ільченко, 2009: 9); Михайлик того разу переносив пані Роксолану легко та зручно, хоч було ие ділом трудненьким, бо ж пані тая, молода й прехороша, товстою ще не стала в свої вісімнадиять років, але вже була тілиста (Ільченко, 2009: 9). Як бачимо, в останньому прикладі характеризують вік героїні (18 років), підкреслюючи цим красу дівчини та їі молодість.

Для чоловіків проблема старіння була не надто суттєвою, тому й указівок на їхній поважний вік та їхню у зв’язку із цим незграбність майже не знаходимо у творі: I став біля вежі, стомлений, зажурений старий козак, що вже стомився від безугавних воєн, які роздирали мирну Украйну протягом століть (Ільченко, 2009: 73); ...старий Мелхиседек (Ільченко, 2009: 291); ...старий єпископ... (Ільченко, 2009: 291).

Як засвічує ілюстративний матеріал, існує чітка розбіжність між розумовими здібностями чоловіка й жінки: чоловіки, на відміну від жінок, з віком стають дедалі розумнішими, досвідченішими, наприклад: Мамай був майстром на всі штуки і вмів робити все на світі, бо ж тоді, в ті простацькі часи, не так уже й багато взагалі вміли робити люди (Ільченко, 2009: 388); - Отож, діти мої, правду каже наш отець Варлам (Ільченко, 2009: 356); ...балакають люди, що нема в світі й козака, мудрішого над Мамая (Ільченко, 2009: 294); .. все він умів, анахтемський Козак Мамай (Ільченко, 2009: 292).

Існує також стереотип, що любити й залицятися доречно в молодому віці, спостерігаємо цей стереотип і в романі: Хлопчина квапився бодай на хвильку побачити свою кохану ще раз, аж під собою землі не чув, аж наче так осліп, нещасний, від тої отрути кохання, що й рівчака не вздрів та заорав туди носом, аж кров пішла, аж загули джмелі в голові, все йому перед очима коливалось, бо здалось йому, 
щзо в той рівчак летів аж надто довго, івже на дальшому иляху назад, до покоїв єпископа на мить не облишало його, бо ж у голові макітрилось, і вся земля наче тікала в небо (Ільченко, 2009: 159); ...поглянув хлопчина й на рушники, наче вгадував, якими пов'яже Ярина його старостів: чи ось такими, хрещиком вишиваними, буковинськими, чи тканими, червоно-білими кролевецькими, б чи полтавськими, мережаними й квітчастими? (Ільченко, 2009: 219); Я прийшов сам. Привело закохане серие (Ільченко, 2009: 309); Коротше кажучи, він здатен був на все, на що бувають здатні закохані молодики, коли їм хочеться співати, перевернути світ, зробити неможливе, море запалити, літати хочеться, на цілий світ кричати про своє сподіване чи несподіване кохання (Ільченко, 2009: 217).

Проаналізувавши дібрані з досліджуваного роману мовні одиниці на позначення вікових стереотипів, можемо сказати, що вони в основному грунтувалися на опозиції молодий - старий. Було визначено, що стереотипних виявів на позначення віку жінок більше, оскільки вони більше значення надають своїй зовнішності, завжди прагнуть бути молодими й привабливими. Жінки часто приховують свій справжній вік, у той час як чоловіки, навпаки, з віком стають розумнішими, досвідченішими й тому не соромляться свого віку.

Соціальні гендерні стереотипи виражені у творі чи не найбільше. Ця група стереотипів змістовна, оскільки в ній представлені різні соціальні ролі чоловіка й жінки: сімейні, професійні, матеріальні. Важливими в аналізі соціальних стереотипів є сімейні ролі.

Передусім наведемо приклади, що стосуються вибору другої половинки. Як бачимо, для чоловіка дуже важливо вибрати собі за дружину добру, хазяйновиту жінку. Тому частіше жінки постають перед нами як такі, що вміють добре хазяйнувати; це підтверджується в такому мікротексті: На срібній тащі в неї були золоті келихи змедом хмільним, з терновим столітнім вином, що від його найменшої крапельки макітрилося в голові навіть у бувалих запорожиів, бо ж не почастувати гостей, як звичай велить, украйнська душа не може навіть у найприкрішу хвилину, навіть на похороні, навіть у скруті війни... Ярина переходила від столу до столу, хоч там уже й порозставляла пані Роксолана свої трунки, та кожен поспішав саме $з$ власних ручок иієї, як кажуть наші брати-поляки, слічної дівчини - пригубити врочисту чарку частування (Ільченко, 2009: 154); 
Роксолана, ввійшовщи до покою, повко розносила на всі столи і столики зелені прозорі кварти, квітчасті череп'яні куманці - з варенухою, з горілками та наливками, дерев'яні михайлики до них, скляні чарки та чари, золоті й срібні кухлі та келехи (Ільченко, 2009: 150); Хоч і були вони бідні, та заради таких проводів знайшлась у домі й чарка на дорогу, і сала шматок на заїдок, і хліба досить, а він же був у Анни завще випечений, як сонще, що й у гетьмана кращого хліба не бува (Ільченко, 2009: 346); - Мені ж наша Лукія до сідла приторочила торбинку пшона, в олії смаженого, торбу тарані, сухариів, буханиів... (Ільченко, 2009: 347); Настя Певна хазяйнувала спритно та швидко, наливала кому горілки, кому кухоль закарпатської паленки, кому тютюнкової, кому перчаківки, кому бариги, кому глечик пива мариьового, запорозького чи батуринського, кому березового соку чи квасу гуиульського з яблук та скорушини, а кому й студеної води (Ільченко, 2009: 424); - А ми оце зібралися підвечіркувати, - вклонилась Анна. - То, може б, ви - з нами? Пора ж таки! (Ільченко, 2009: 343); Ярина Подолянка, молодесенька господиня, мала бажання добре почастувати гостя... (Ільченко, 2009: 292); Їв хлопець швидко, в смак, складаючи добру иіну куховарському хистові привітної господині (Ільченко, 2009: 344).

Знаходимо й стереотипи, які вказують на необхідність шлюбу, на те, що шлюб - невід'ємна частина життя людини й невід'ємний складник продовження роду, наприклад: - Лихо ж моє чубатоє, ніхто мене не сватає! - і знов зітхнула: - Скільки ж ие ми років з тобою... ось так? - Давно... все ж перемінилось довкола. Поглянь! Ось тут був млин, вітряк, і нема вже того вітряка (Ільченко, 2009: 385); - Ех, коли б... Дав нам Бог! - зітхала й стара дівиия. - То було б у нас дітей із десяточок... - Нічого в Бога більше й не благала б (Ільченко, 2009: 386). Мовний матеріал засвідчує, що для жінок шлюб і діти були найголовнішими в житті, проте водночас зазначено, що для чоловіків сім'я не стоїть на першому місці, тому вони готові пожертвувати нею заради інших «чоловічих справ»: Мені ж ось інколи, душі козацькій, дитя поколисати хочеться: але жн жінки, ні дитинки, - $і$ я стинаю голови врагам (Ільченко, 2009: 296); - Я хотів би й неба прихилити. А війна ж за війною. А смерть так і ходить круг наших людей! I не можу покинути січове товариство, щоб назавще прибути до тебе, щастя моє лютеє, дівко моя скажена: комусь - як мара, а мені - як зоря! 
(Ільченко, 2009: 385); Пан сотник, правда, за всі ті години про Параску навіть не згадав, бо в нього клопоту й без неї набралося досить (Ільченко, 2009: 543).

Наведені вище приклади підтверджують, що жінка для чоловіка $є$ невід’ємним атрибутом його достатку й сімейного благополуччя. 3 проаналізованих прикладів (соціальні ролі «чоловік - дружина») можемо зробити висновок, що мовних виявів, які вказують на ставлення чоловіка до жінки, його оцінку набагато більше, ніж тих, де жінка висловлює своє ставлення чи оцінку до чоловіка. Це означає, що за своєю природою жінка створена спокійнішою істотою, здатною підкорятися і йти на компроміси. Однак це знову ж таки всього лише стереотип, а не точна й однозначна характеристика жінки.

У суспільстві часто наголошують на тому, що соціальна роль жінки набагато важливіша: жінка - це передусім дружина й мати. О. Ільченко приділяє значну увагу цим іiі функціям. Тому ще однією важливою соціальною роллю жінки є материнство. У мовних одиницях, що характеризують жінку як матір, переважають такі значення як доброта, розуміння, мудрість, любов, наприклад: - Мій цвіркунчику, шепотіла над парубком мати,- моє зозулятко! Кучерявчику мій, пострибунчику! Лебедику мій прехороший! Патретику мій достеменненький!.. Ти ж, бач, вузличок мій тугенький! Горобчику мій проворненький... - $і$ доброта материнська струміла з усіх зморшок іï чистого та виразного лиия, доброта до всього й до всіх, доброта в голосі, в погляді, в будь-якім русі, в зітханні, в розмові, в мовчанні, доброта, як те й належить матері, будь-якій матері, всім матерям всіх часів і народів, матері, неньці, мадонні, яку Господь Бог створив задля добра, задля миру, задля сліз, проливаних тисячоліттями - над помилками й прогріхами нерозумних дітей, хоч Явдоха, правда, й не плакала зараз, але все-таки ій чогось було сумно, як і завше матері, щзо схилилась над сином, котрий став на порі (Ільченко, 2009: 19); Стало наче трохи світліше, бо вже благословлялось на світ, і матінка бачила кожен рух Михайлика, і намагалася бути коло нього, але щцоразу в січі відбивалася геть (Ільченко, 2009: 99); Хочеш сина послати на певну смерть?- Е-е, ні, - сказала матінка. - Він дійде живий! Він хіба знає дорогу? - Та я ж сама піду з ним, пане (Ільченко, 2009: 147); Потягла в другий бік свого синочка й матінка, бо той рвонувся був до пана Пампушки: відчуття польоту ще тривало, і хлопець ще 
й сам не знав, чого може накоїти спрожогу, і треба було одвести од гріха, і матінці ще дужче засвербіло хутчіш вибратися з иьього небезпечного й повного всякими несподіванками людського моря, яке зветься базаром (Ільченко, 2009: 226); - Хтозна - повела плечиком і Явдоха, що завжди й з'являлася біля свого синочка в найпотрібнішу мить (Ільченко, 2009: 429).

У зазначених вище контекстах відзначається, що, незалежно від того, які риси має мати й чи відповідає вона всім висуненим суспільством вимогам, вона все одно для своєї дитини найкраща й найрідніша людина, та, навпаки, кожна мати розуміє переваги й недоліки своєї дитини, але це ніколи не впливає на сильне материнське почуття, що, згідно зі стереотипами, найнадійніше в житті.

Згідно зі стереотипом основні функції матері оберігати, годувати й виховувати дітей, наприклад: Мати оберігала сон Михайликів, хоч парубок, перевернувшись горічерева, спати й гадки не мав (Ільченко, 2009: 19); Але Явдоха, мати, як тевиия, відбороняла молодого коваля від посягання примхливої пані, бо страшнішого за це для будьякої матінки нічого бути не могло (Ільченко, 2009: 51); Коли Мамай раптово виник біля кузні, Михайлик самотужки перекочував зняту з коліс гармату, а Явдоха, як і завжди, метушилась круг сина, силуючись йому допомогти (Ільченко, 2009: 390).

Однак водночас існує стереотип, що надмірна увага матері може розбестити сина чи дочку. Особливо негативно розбещення впливає на чоловіка, пояснюють це тим, що він, стаючи «матусиним синком», утрачає так званий «чоловічий стержень» і не може самостійно впоратись із труднощами життя, а тим паче сімейного життя. У романі знаходимо деякі факти, що $є$ підтвердженням цього: А Михайлик покірно поплентав за мамою. Явдоха вела його за руку і говорила так, немов ніяка материнська тривога зараз оце не шарпала їі серие (Ільченко, 2009: 15); Михайлик, котрий усі иі дні біг верхи поміж козаками та джурами, а зараз оце разом зі своєю матінкою саме оглядав підкови на шестерику притомлених коней - змїв, що їх тільки-но випрягли з ридвана (Ільченко, 2009: 8); ...nідклав собі кулак під щоку та й блимав, ненароком неначе, на той вибалок, куди поніс пампушка свою пані, аж поки неня не повернула його носом до небес (Ільченко, 2009: 18); Взявши за руку, Явдоха потягла синочка через порожній базарний майдан (Ільченко, 2009: 419). 
Значно менше фіксуємо в романі виявів чоловіків як батьків та сім'янинів, але необхідно зазначити, що XVII століття - це неспокійний для України час, тому передусім чоловіки були покликані захищати свої землі. Проте знаходимо приклад того, що для чоловіка мати сім’ю також важливо: Один серед безмірного степу, Козак Мамай, зустрічаючи ранок нового дня, співав про те, в чім він не признався 6 нікому: про мрію невгасиму - не тинятисв по світі, воюючи й бешкетуючи, икилюючи й жартуючи, а мати б свою хатину, дружиноньку вірну, дрібних дітей (Ільченко, 2009: 127).

Як чоловіки, так і жінки займають певну позицію в суспільстві. За проаналізованим мовним матеріалом можемо стверджувати, що жінки не брали участі в політичному житті суспільства, рідко працювали, щоб заробляти гроші.

Чоловіки ж постають перед нами як такі, що прагнуть до влади й збагачення. Чоловік за своєю природою завжди прагне керувати, зокрема вияви високого соціального статусу чоловіків знаходимо й у досліджуваному творі, наприклад: пан сотник... (Ільченко, 2009: 543); Поки пан Стародупський, як і годиться обозному, порядкував у городi, на пороховому млині, в пекарнях, салотопнях та кузнях, архієрей, як і належить полковникові, мчав риссю до Коронного замку, де так нагло знову озвалась війна... (Ільченко, 2009: 457); Заміри в Пампушки, як ми вже знаємо, були преширокі, і пан обозний сподівався, спаливщи тоді купу тадану, скоренько знайти в Калиновій Долині запорозькі скарби, силу - силенну золота, щоб стати на Вкраїні магнатом і володарем (Ільченко, 2009: 297); Ставши поміж козаками великим паном, Пампушка вже не терпів, щоб йому перебаранчав хтось у будь-якому ділі (Ільченко, 2009: 36); Підвладні ясновельможного гетьмана України, кому кортіло заслужити високий чин, посаду, грошики чи просто похвалу, в усьому намагалися наслідувати свого володаря (Ільченко, 2009: 110); Владика, правда, вже й захекався досить помітно, але, як і годилось козацькому полковникові, ощадку в Мамая не просив (Ільченко, 2009: 299); То й що там могло привернути увагу такого вельможного й вельми закоханого (як казав колись Цицерон про Помпея), закоханого в себе самого без суперника, - що ж там могло привернути високу увагу такого пана: степ та й степ (Ільченко, 2009: 6); I не стерпів той чвань зневаги до рангу свого, одступив на крок від голубого ридвана й загукав на чумаків огидним панським 
полубаском (Ільченко, 2009: 24); Я ж, бач, свого нічого й нікому не відступив, - на те я й справжній пан (Ільченко, 2009: 248); Напинаючи на себе пишні штани, пан обозний поглядав вздовж дороги, погейкував на слуг, покивував на старішого джуру (Ільченко, 2009: 22). Як бачимо, чоловіки постають перед нами, як такі, що завжди прагнуть до влади, до високого соціального становища.

Вагоме значення для чоловіків має не лише суспільний статус, але й матеріальне становище. Чоловіки постійно прагнуть до збагачення, у такий спосіб самостверджуючись: - Грошей, грошей! - I Купа аж поперхнувся: розмова иял $і$ йому шарпала душу, бо ж він був жадібний до червінчиків, хоч $і$ не добирав того, що побрязкачі - для розумного лише могутній засіб, а для дурноверхого - сама изіль... (Ільченко, 2009: 30); Нічого за душею не мавши, крім грошей і нахабства, він зазіхав на булаву, тож і наміри свої розкрити він не міг нікому, навіть шлюбній дружині, бо страшився - чи не гетьманською пронозою лягла вона йому в постіль? (Ільченко, 2009: 297)

Жінці притаманний виконавчий характер праці, прислужування, часто експресивна сфера діяльності. Але, попри це, жінки любили й поважали своїх чоловіків, наприклад: Пан Оврам був чоловіком мирославському обозному потрібним, ось чому Демид Пампушка й звелів молоденькій дружиноньиі якнайкраще його привітати, скільки стане снаги догоджати дорогому гостеві (Ільченко, 2009: 304); - Може, коли й буде, а поки щъо... - і вона вклонилася панові Пампушиі. - Служила я тобі аж двадиять і п'ять год, а не заслужила, бач, ні вола, ні коня, ані доброго слова від тебе, пане чваньку, колишній козаче запорозький (Ільченко, 2009: 57); - А хто ж парубків милуватиме? - ворухнувши вусом, спитав старий гончар (Ільченко, 2009: 329); Ходім лишень! - рвонувши Козака за руку, наказала Лукія з таким виразом тонкого й уже трохи вислого немолодого обличчя, який нічого втішного Мамаєві не вімував. - Іди! - стиха мовив Мамай. - Наздожену. Лукія рушила вперед (Ільченко, 2009: 376); - Отак-то, пане Купо! мовила тим часом Лукія, гончарівна, але раптом виструнчилась перед полковим обозним і спитала поважливо: - Дозвольте слово мовити, вельможний пане? Лукія вела та й вела свого коханого за руку, наче якогось малолітка, $і$ Козакові од ії руки ставало то зимно, то жарко, а причаєна тиша в обложеному городі непокоїла й дратувала Козака більше за будь-який гуркіт, бо в нійжило й напруження 
війни, і сподівання неспокійної ночі проти Зеленої неділі, коли вся нечиста сила виступає на православних християн (Ільченко, 2009: 381); - Ні. Мій коханий Демид ще мені не огид (Ільченко, 2009: 16); Лукія, діждавшись, нарешті, поки Мамай наздогнав їі, мовчки йшла з ним по місту, ввечері насторожено притихлому, - нарешті, нарештітаки - тільки вдвох... (Ільченко, 2009: 381); Він міркував про щзось, записував і знову завмирав у роздумі. А Чужа Молодиия, поглядаючи скоса, зизувата, ходила круг нвого навшпиньках. Свічок так-таки $\breve{u}$ не гасила, хоч уже й заходив ясний неділешній ранок, ранній ранок червня (Ільченко, 2009: 436).

У процесі аналізу з'ясовано, що найважливішими пріоритетами життя для жінки є сім'я, діти, чоловік, а для чоловіка - влада, гроші, сім’я. В україномовній картині світу XVII століття переважають такі стереотипи: жінка - добра, лагідна, турботлива, піклується про дітей і добробут у домі, хороша господиня. Чоловік забезпечує матеріальний благоустрій сім’ї, розумний, досвідчений, є авторитетом, найважливіше його завдання - відповідально поставитися до вибору дружини.

\section{Висновки}

Отже, гендерні стереотипи закріплюють у мові властиві для того чи того народу особливості менталітету, і за їх допомогою можна дослідити наявні етнолінгвістичні норми гендерної культури. У цьому контексті увагу було звернено на роман О. Ільченка «Козацькому роду нема переводу...» як на твір художньої літератури, у якому висвітлено гендерні стереотипи минулого. Аналіз гендерних стереотипів на позначення віку, зовнішності, соціальних ролей і психологічних особливостей дав змогу зробити висновок, що більшість із них знаходять свою реалізацію і в наш час.

Зокрема, жінка більшого значення надає своїй зовнішності, завжди прагне бути привабливою і молодою, а для чоловіків вік не є таким важливим, адже з роками вони стають розумнішими, досвідченішими. Досліджені стереотипи зовнішності доводять наявність таких стереотипізованих рис у чоловіків: високий, сильний, міцний, з гарним волоссям; у жінки: вродлива, струнка (або схильна до повноти), з гарним волоссям, доглянутим тілом і приємними рисами обличчя. 
3’ясовано, що соціальні стереотипи виражені передусім сімейними ролями: велика увага приділяється ролі матері та дружини, чоловіки ж більше віддані політиці. Позитивно оцінюється вірна, добра, гарна жінка, яка водночас є хорошою господинею, і сильний, сміливий чоловік, який може стояти на чолі сім’ї, забезпечувати іiі.

Поведінка людини, риси іï характеру часто проявляються і, відповідно, виникає багато стереотипних установок, які стосуються саме психології людини, іiі внутрішнього світу. Виокремлені психологічні стереотипи дали змогу дійти висновку, що відчутним $є$ позитивна оцінка чоловіка (сильні, вольові, розумні, надійні, рішучіші, цілеспрямовані та наполегливі) й часто негативна жінки (балакучіші, ненадійні, емоційні, конфліктніші й не такі розумні, як чоловіки). Однак кожна людина має свій психологічний портрет (набір позитивних і негативних рис), що не завжди формується на основі наявних у суспільстві стереотипів.

У подальших розвідках заплановано продовжити дослідження заявленої проблеми як перспективного напряму гендерної лінгвістики.

\section{ЛІТЕРАТУРА}

1. Горностай, П. П. (2010). Гендерний розвиток та гендерна ідентичність особистості. Психологія. Узято з https://ru.osvita.ua/vnz/reports/psychology/9815/. 2. Городяненко, В. Г. (2003). Основні положення гендерної соціології. Узято з http://ebk. net.ua/Book/sociology/gorodyanenko_sotsiologiya/part3/31402.htm. 3. Горошко, Е. И. (2001). Гендерная проблематика в языкознании. Введение в гендерные исследования. (Ч. 1). Сакт-Петербург: Алетейя. 4. Ільченко, О. Є. (2009). Козацькому роду нема переводу, або ж Мамай і Чужа Молодиия. Харків: Фоліо. 5. Основи теорії sендеру (2004). Київ: “К.І.С.” 6. Помирча, С.В. (2009). Вербальне вираження етнопсихічних архетипів у романі О. Ільченка «Козацькому роду нема переводу...». (Автореф. дис. ... канд. філол. наук). ХНПУ імені Г. С. Сковороди. 7. Сбітнєва, І. (2009). Біблія - репрезент концептуальної картини світу. Лінгвістичні студіï, 18, 283-287.

\section{REFERENCES}

1. Hornostai, P. P. (2010). Hendernyi rozvytok ta henderna identychnist osobystosti [Gender development and gender identity]. Psykholohiia - Psychology. Retrieved from: https://ru.osvita.ua/vnz/reports/psychology/9815/ [in Ukrainian]. 2. Horodianenko, V. H. (2003). Osnovni polozhennia hendernoi sotsiolohii [The main provisions of gender sociology]. Retrieved from: http://ebk.net.ua/Book/sociology/gorodyanenko_sotsiologiya/ part3/31402.htm [in Ukrainian]. 3. Goroshko, E. I. (2001). Gendernaya problematika v yazykoznanii. Vvedenie $v$ gendernye issledovaniya [Gender issues in linguistics. Introduction to Gender Studies]. (Vol. 1). Sankt-Peterburg: Aleteyya [in Russian]. 4. Ilchenko, O. Ye. (2009). Kozatskomu rodu nema perevodu, abo zh Mamai i Chuzha Molodytsia [The Cossack Family will not Die out, or Mamai and a Stranger Girl]. Kharkiv: Folio [in Ukrainian]. 
5. Osnovy teorii genderu (2004) [Fundamentals of gender theory]. Kyiv: "K.I.S." [in Ukrainian]. 6. Pomyrcha, S. V. (2009). Verbalne vyrazhennia etnopsykhichnykh arkhetypiv u romani O. Ilchenka «Kozatskomu rodu nema perevodu...» [Verbal expression of ethnopsychic archetypes in O. Ilchenko's novel “The Cossack Family will not Die out...”]. Extended abstract of candidate's thesis. KNPU imeni H. S. Skovorody [in Ukrainian]. 7. Sbitnieva, I. (2009). Bibliia - reprezent kontseptualnoi kartyny svitu [The Bible is a representative of the conceptual picture of the world]. Linhvistychni studii - Linguistic Studies, 18, 283-287 [in Ukrainian].

Лобачова Ірина Миколаӥвна - кандидат філологічних наук, доцент, доцент кафедри теорії і практики початкової освіти, ДВНЗ «Донбаський державний педагогічний університет»; вул. Шовковична, 27/54, м. Слов'янськ, Донецька обл., 84122, Україна.

Tel.: +38-050-874-11-26

E-mail: sbitneva.irina@ukr.net

http://orcid.org/0000-0001-7102-1915

Lobachova Iryna Mykolaivna - Candidate of Philological Sciences (Ph.D.), Docent, Associate Professor at the Department of Theory and Practice of Primary Education, SHEI "Donbas State Pedagogical University"; 27/54 Shovkovychna Str. Sloviansk, Donetsk Region, 84122, Ukraine.

Помириа Світлана Вікторівна - кандидат філологічних наук, доцент, доцент кафедри теорії і практики початкової освіти, ДВНЗ «Донбаський державний педагогічний університет»; вул. Батюка, 10/39, м. Слов’янськ, Донецька обл., 84116, Україна.

Tel.: +38-099-028-54-78

E-mail: swetlanapom@gmail.com

https://orcid.org/0000-0003-1636-3239

Pomyrcha Svitlana Viktorivna - Candidate of Philological Sciences (Ph.D.), Docent, Associate Professor at the Department of Theory and Practice of Primary Education, SHEI "Donbas State Pedagogical University"; 10/39 Batiuka Str., Sloviansk, Donetsk Region, 84116, Ukraine.

Надійшла до редакції 23 лютого 2021 року

\section{CITATION}

ДСТУ 8302:2015: Лобачова I. М., Помирча С. В. Функціонування гендерних стереотипів у романі О. Ільченка «Козацькому роду нема переводу...». Лінгвістичні дослідження: зб. наук. пр. Харк. нац. пед. ун-ту імені Г. С. Сковороди. Харків, 2021. Вип. 54. Ч. І. С. 103-119. DOI: https://doi.org/10.34142/23127546.2021.54.1.09

APA: Лобачова, I. М., \& Помирча, С. В. (2021). Функціонування гендерних стереотипів у романі О. Ільченка «Козацькому роду нема переводу...». Лінгвістичні дослідження, 54 (I), 103-119. DOI: https://doi.org/10.34142/23127546.2021.54.1.09 